\author{
Factors Related to Cognitive Function in Elderly People \\ Fransiska Y.D. Mardiyanto*, Dedeh S. Jahja ${ }^{\text {*** }}$, Yenni Limyati ${ }^{* * *}$ \\ *Faculty of Medicine Maranatha Christian University \\ **Neurology Department Faculty of Medicine Maranatha Christian University \\ Jl. Prof. Drg. Suria Sumantri MPH No. 65 Bandung 40164 Indonesia \\ *** Physical Medicine and Rehabilitation Department Immanuel Hospital Bandung \\ Jl. Kopo No. 161 Bandung 40234 \\ Email: yandevina0327@gmail.com
}

\begin{abstract}
Each year in the world, especially in Indonesia, many elderly people exposed to higher risk of dementia due to an increased number of the elderly population and the incidence of mild cognitive impairment in the elderly. The aim of this study is to find out what factors are related with cognitive function in the elderly population. The study used analytic method with cross sectional study design. Subjects were 60 elderly people; male or female $\geq 60$ years old. Data were analysed with Chi Square Test $(\alpha=0.05)$. Cognitive function was measured by MMSE test. The result were found a significant relation between age and cognitive function ( $p=$ 0.014 ), level of education and cognitive function ( $p$ value $=0.000$ ), physical activity and cognitive function ( $p$ value $=0.003$ ), cognitive activity and cognitive function ( $p$ value $=0.002$ ), and social interaction and cognitive function $(p$ value $=0.000$ ). Gender variable did not have relation with cognitive function ( $p$ value $=0.343$ ). This study conclude that there was a relation between age, education level, physical activity, cognitive activity and social interaction with cognitive function in the elderly population. There was no relation between gender and cognitive function in the elderly population.
\end{abstract}

Keywords: cognitive function, cognitive impairment, elderly, MMSE 


\title{
Faktor - Faktor yang Berhubungan dengan Fungsi Kognitif pada Populasi Lansia
}

\author{
Fransiska Y.D. Mardiyanto*, Dedeh S. Jahja**, Yenni Limyati**** \\ *Fakultas Kedokteran Universitas Kristen Maranatha \\ **Bagian Neurologi Fakultas Kedokteran Universitas Kristen Maranatha \\ Jl. Prof. Drg. Suria Sumantri MPH No. 65 Bandung 40164 Indonesia \\ *** Bagian Rehabilitasi Medik Rumah Sakit Immanuel Bandung \\ Jl. Kopo No. 161 Bandung 40234 \\ Email: yandevina0327@gmail.com
}

\begin{abstract}
Abstrak
Tiap tahun di dunia, khususnya di Indonesia, banyak lansia berisiko tinggi terkena penyakit dementia ditunjukan dengan adanya peningkatan jumlah populasi dan insidensi penurunan kognitif ringan pada lansia. Tujuan penelitian ini adalah untuk mengetahui faktor faktor yang berhubungan dengan fungsi kognitif pada lansia. Penelitian ini menggunakan metode analitik dengan desain studi cross sectional. Subjek penelitian adalah 60 lansia yang berusia $\geq 60$ tahun saat penelitian dimulai. Analisis statistik menggunakan chi square test dengan $\alpha=0,05$. Fungsi kognitif diukur dengan pemeriksaan MMSE. Hasilnya didapatkan hubungan yang signifikan antara umur dengan fungsi kognitif $(p=0,014)$, tingkat pendidikan dengan fungsi kognitif ( $p=0,000)$, aktivitas fisik dengan fungsi kognitif $(p=0,003)$, aktivitas kognitif dengan fungsi kognitif $(p=0,002)$, dan interaksi sosial dengan fungsi kognitif $(p=$ $0,000)$. Pada variabel jenis kelamin, tidak didapatkan hubungan yang signifikan dengan fungsi kognitif $(p=0,343)$. Dari penelitian ini disimpulkan terdapat hubungan antara umur, tingkat pendidikan, aktivitas fisik, aktivitas kognitif, dan interaksi sosial dengan fungsi kognitif pada populasi lansia. Tidak terdapat hubungan antara jenis kelamin dengan fungsi kognitif pada populasi lansia.
\end{abstract}

Kata kunci: fungsi kognitif; gangguan kognitif; lansia; MMSE 


\section{Pendahuluan}

Di seluruh dunia saat ini jumlah lanjut usia diperkirakan lebih dari 629 juta jiwa (satu dari 10 orang berusia lebih dari 60 tahun) dan pada tahun 2025 jumlah lanjut usia diperkirakan akan mencapai 1,2 milyar. Secara demografis, berdasarkan sensus penduduk pada tahun 2000, penduduk berusia 60 tahun ke atas berjumlah 17,8 juta jiwa ( $8 \%$ dari jumlah penduduk), pada tahun 2005 meningkat menjadi 20 juta jiwa (8,5\% dari jumlah penduduk) dan pada tahun 2010 meningkat menjadi 24 juta jiwa (9,8\% dari jumlah penduduk). Pada tahun 2020 jumlah ini diperkirakan meningkat menjadi 28,9 juta jiwa (11,4\% dari jumlah penduduk). Hal ini menunjukkan bahwa jumlah populasi lanjut usia mengalami peningkatan setiap tahunnya. ${ }^{1}$

Indonesia merupakan negara tertinggi dalam pertumbuhan penduduk lanjut usia dalam kurun waktu 1990-2010, sehingga Indonesia menduduki peringkat empat sebagai negara berpenduduk lanjut usia terbanyak di dunia setelah China, India, dan Amerika Serikat. ${ }^{2}$ Berdasarkan hasil Susenas tahun 2013, jumlah lansia di Indonesia mencapai 20,04 juta orang atau sekitar $8,05 \%$ dari seluruh penduduk Indonesia. ${ }^{3}$

Meningkatnya populasi lansia mengakibatkan terjadinya transisi epidemiologi, yaitu bergesernya pola penyakit dari penyakit infeksi dan gangguan gizi menjadi penyakit - penyakit degeneratif seperti diabetes, hipertensi, neoplasma, dan penyakit jantung koroner. ${ }^{4}$ Gangguan akibat penurunan fungsi lainnya yang sering terjadi pada lansia adalah yang berhubungan dengan fungsi kognitif. Menurunnya kemampuan kognitif pada lansia sering dianggap hal yang wajar dialami oleh semua lansia. ${ }^{5}$ Padahal gangguan kognitif sedang sampai berat, jika dibiarkan terus menerus akan berkembang menjadi penyakit yang lebih serius, seperti penyakit Alzheimer. ${ }^{6}$

Insidensi dari Mild Cognitive Impairment (MCI) atau penurunan kognitif ringan pada lansia semakin meningkat dari $7 \%$ hingga $18 \%$. Lansia yang mengalami penurunan kognitif ringan, memiliki risiko $14 \%$ lebih tinggi terkena dementia. ${ }^{7}$ Oleh karena itu, fungsi kognitif pada lansia tetap perlu dipertahankan agar terhindar dari penyakit - penyakit degeneratif seperti dementia. Salah satu upaya yang dapat dilakukan yaitu dengan mengidentifikasi dan mengendalikan faktor - faktor yang dapat mempengaruhi fungsi kognitif pada lansia.

Berdasarkan latar belakang tersebut maka perlu dilakukan penelitian mengenai faktor faktor yang berhubungan dengan fungsi kognitif pada populasi lansia. Tujuan dari penelitian ini adalah untuk mengetahui apakah faktor usia, jenis kelamin, tingkat pendidikan, aktivitas fisik, aktivitas kognitif, dan interaksi sosial berhubungan dengan fungsi kognitif pada lansia. Perbedaan penelitian ini dengan penelitian sebelumnya yaitu variabel yang diteliti lebih banyak, 


\section{Research Article}

selain itu masih sangat sedikit bahkan belum ada yang melakukan penelitian seperti ini pada lansia di kota Bandung.

\section{Metode}

Penelitian ini dilakukan di Panti Jompo DORKAS Bandung dan Gereja Pandu Bandung berlangsung dari bulan Januari - Oktober 2016, dilakukan menggunakan desain penelitian cross sectional.

Alat dan bahan yang digunakan pada percobaan ini adalah lembar pemeriksaan Mini Mental State Examination (MMSE) dan lembar Index Social Disengagement sejumlah banyaknya responden. Subjek penelitian adalah 60 lansia yang ada di Panti Jompo DORKAS dan Gereja Pandu yang memenuhi kriteria inklusi: laki-laki atau perempuan $\geq 60$ tahun saat penelitian dimulai dan bersedia mengikuti penelitian ini dengan kriteria eksklusi: tidak dapat berkomunikasi dengan baik dan tidak dapat melihat. Penelitian ini dilakukan dengan cara mewawancarai subjek penelitiannya dan juga melibatkan indera penglihatan untuk menggambar pada pengukuran fungsi kognitifnya sehingga kemampuan berkomunikasi dan melihat merupakan hal yang penting.

Pada penelitian ini, pengukuran fungsi kognitif dilakukan dengan Mini Mental State Examination (MMSE). Kuesioner yang terdiri dari 30 poin dalam 11 pertanyaan ini digunakan untuk skrining gangguan kognitif, dengan durasi pemeriksaannya sekitar 5-10 menit. Penilaiannya menggunakan single cut off, yaitu fungsi kognitif terganggu jika skor $<24$ dan normal jika skor $\geq 24$. Penilaian variabel usia, jenis kelamin, dan tingkat pendidikan dilakukan dengan wawancara biasa dan observasi, sedangkan penilaian variabel aktivitas fisik, aktivitas kognitif dan interaksi sosial menggunakan Index Social Disengagement. Pengisian kuesioner yang terdiri dari 38 poin ini dilakukan dengan wawancara, dan memerlukan waktu 1015 menit. Variabel usia digolongkan menjadi usia lanjut (60 - 74 tahun) dan usia lanjut tua (75 - 90 tahun). Variabel jenis kelamin digolongkan menjadi laki - laki dan perempuan. Variabel tingkat pendidikan digolongkan menjadi tingkat pendidikan dasar (SD/SMP), menengah (SMP), dan tinggi (diploma, sarjana, magister, spesialis). Variabel aktivitas fisik, aktivitas kognitif dan interaksi sosial digolongkan menjadi baik dan buruk sesuai dengan penilaian pada Index Social Disengagement.

Data yang diperoleh dianalisis secara univariat untuk melihat gambaran fungsi kognitif, usia, jenis kelamin, tingkat pendidikan, aktivitas fisik, aktivitas kognitif, dan interaksi sosial. Selanjutnya data dianalisis secara bivariat antara fungsi kognitif responden dengan penilaian setiap variabel yang sudah dianalisis secara univariat, menggunakan uji chi-square dengan $\alpha=$ 


\section{Research Article}

0,05 dan perhitungannya menggunakan program SPSS. Penelitian ini telah mendapatkan persetujuan etik dari Komisi Etik Universitas Kristen Maranatha dengan surat keputusan komisi etik nomor: 095/KEP/V/2016.

\section{Hasil}

Berdasarkan penelitian yang telah dilakukan pada 60 responden yang berusia $\geq 60$ tahun diperoleh hasil sebagai berikut:

Tabel 1 Karakteristik Responden Penelitian

\begin{tabular}{lcc}
\hline \multicolumn{1}{c}{ Karakteristik (n= 60) } & Jumlah (orang) & Persentase (\%) \\
\hline 1. Usia & 24 & 46,67 \\
$\quad$ Lanjut usia $(60-74$ tahun) & 36 & 53,33 \\
Lanjut usia tua $(75-90$ tahun) & & 20 \\
2. Jenis Kelamin & 12 & 80 \\
$\quad$ Laki-laki & 48 & \\
$\quad$ Perempuan & & 48,3 \\
3. Tingkat Pendidikan & 29 & 21,7 \\
$\quad$ Dasar & 13 & 30 \\
Menengah & 18 & \\
Tinggi & & 46,67 \\
4. Aktivitas Fisik & 28 & 53,33 \\
$\quad$ Baik & 32 & 61,67 \\
Buruk & & 38,33 \\
5. Aktivitas Kognitif & 37 & \\
Baik & 23 & 73,33 \\
Buruk & & 26,67 \\
6. Interaksi Sosial & 44 & \\
$\quad$ Baik & 16 & 25 \\
$\quad$ Buruk & & 75 \\
7. Fungsi Kognitif & 15 & \\
$\quad$ Terganggu & 45 & \\
Normal & &
\end{tabular}

Selanjutnya hubungan antara variabel - variabel yang diteliti dengan fungsi kognitif dianalisis secara statistik menggunakan chi square test dengan $\alpha=0,05$. Dari tabel 2 di bawah ini dapat dilihat bahwa variabel usia, tingkat pendidikan, aktivitas fisik, aktivitas kognitif, dan interaksi sosial memiliki hubungan dengan fungsi kognitif, namun yang paling signifikan hubungannya adalah variabel tingkat pendidikan dan interaksi sosial. Sedangkan variabel jenis kelamin dilihat dari $p$ value-nya, tidak memiliki hubungan dengan fungsi kognitif. 
Tabel 2 Hubungan Variabel - Variabel yang Diteliti dengan Fungsi Kognitif Lansia

\begin{tabular}{|c|c|c|c|c|c|}
\hline & \multirow{2}{*}{ Variabel } & \multicolumn{2}{|c|}{ Fungsi Kognitif } & \multirow{2}{*}{ p value } & \multirow{2}{*}{ Interpretasi } \\
\hline & & Terganggu n $(\%)$ & Normal n (\%) & & \\
\hline \multicolumn{6}{|c|}{ 1. Usia } \\
\hline & Lanjut Usia & $2(8)$ & $22(92)$ & $0,014^{*}$ & Signifikan \\
\hline & Lanjut Usia Tua & $13(36)$ & $23(64)$ & & \\
\hline \multicolumn{6}{|c|}{ 2. Jenis Kelamin } \\
\hline & Laki - laki & $4(33)$ & $8(67)$ & $0,343^{\mathrm{ps}}$ & Tidak Signifikan \\
\hline & Perempuan & $11(23)$ & $37(77)$ & & \\
\hline \multicolumn{6}{|c|}{ 3. Tingkat Pendidikan } \\
\hline & Dasar & $11(58)$ & $8(42)$ & $0,000^{* *}$ & Sangat Signifikan \\
\hline & Menengah & $3(16)$ & $16(84)$ & & \\
\hline & Tinggi & $1(5)$ & $21(95)$ & & \\
\hline \multicolumn{6}{|c|}{ 4. Aktivitas Fisik } \\
\hline & Baik & $2(7)$ & $26(93)$ & $0,003^{* *}$ & Sangat Signifikan \\
\hline & Buruk & $13(41)$ & $19(59)$ & & \\
\hline \multicolumn{6}{|c|}{ 5. Aktivitas Kognitif } \\
\hline & Baik & $4(11)$ & $33(89)$ & $0,002^{* *}$ & Sangat Signifikan \\
\hline & Buruk & $11(48)$ & $12(52)$ & & \\
\hline \multicolumn{6}{|c|}{ 6. Interaksi Sosial } \\
\hline & Baik & $1(5)$ & $43(95)$ & $0,000^{* *}$ & Sangat Signifikan \\
\hline & Buruk & $14(88)$ & $2(12)$ & & \\
\hline
\end{tabular}

Keterangan:

* $\quad$ : Perbedaan bermakna dengan nilai $\mathrm{p}<0,05$

** $\quad$ : Perbedaan sangat bermakna dengan nilai $\mathrm{p}<0,01$

ns $\quad$ : Perbedaan tidak bermakna dengan nilai $\mathrm{p}>0,05$

\section{Diskusi}

Hasil data dari 60 orang responden proporsi lansia yang sudah mengalami gangguan fungsi kognitif adalah sebesar 25\%. Proporsi hasil penelitian ini hampir sama dengan penelitian yang dilakukan oleh Rachmawati dan Puspitosari (2008) ${ }^{8}$ terhadap 32 lansia di PSTW Budhi Luhur Kasongan, Bantul, dengan persentase lansia yang sudah mengalami gangguan fungsi kognitif sebesar 31,25\%. Penelitian yang dilakukan Di Carlo et al. (2000) ${ }^{9}$ terhadap 3.425 lansia di Italia yang berusia 65 - 85 tahun dengan menggunakan instrumen MMSE menunjukkan prevalensi CIND (Cognitive Impairment - No Dementia) sebesar 10,7\%.

Hasil penelitian ini didukung oleh penelitian yang dilakukan oleh Scanlan et al. $(2007)^{10}$ dan Rait et al. (2005) ${ }^{11}$ yang menunjukkan adanya hubungan antara usia dengan penurunan fungsi kognitif dengan nilai $\mathrm{p}<0,05$. Dikatakan perubahan fungsi kognitif yang 


\section{Research Article}

terjadi pada lansia meliputi berkurangnya kemampuan meningkatkan fungsi intelektual dan berkurangnya efisiensi tranmisi saraf di otak yang menyebabkan proses informasi melambat dan banyak informasi hilang selama transmisi. Penurunan menyeluruh pada fungsi sistem saraf pusat dipercaya sebagai kontributor utama perubahan dalam kemampuan kognitif dan efisiensi dalam pemrosesan informasi. ${ }^{10}$ Sjahrir et al yang telah meneliti fungsi kognitif 473 responden di Medan menggunakan kuesioner MMSE mengemukakan bahwa skor MMSE dipengaruhi oleh usia dan tingkat pendidikan. ${ }^{12}$ Francisco et al dalam penelitian meta analitik yang dilakukannya, menyimpulkan bahwa tingkat pendidikan seseorang merupakan faktor resiko terjadinya demensia terutama penyakit Alzheimer, yaitu semakin rendah tingkat pendidikan seseorang maka semakin tinggi risiko terkena demensia Alzheimer. ${ }^{13}$ Tingkat pendidikan yang rendah berhubungan dengan penurunan fungsi kognitif yang dapat terjadi lebih cepat dibandingkan dengan tingkat pendidikan yang tinggi. Suatu teori menjelaskan tentang synaptic reserve hypothesis, dimana orang yang berpendidikan tinggi mempunyai lebih banyak sinaps di otak dibanding orang yang berpendidikan rendah. Ketika sinaps tersebut rusak karena ada proses penyakit misalnya seperti Alzheimer, maka sinaps yang lain akan menggantikan sinaps yang rusak tadi.

Hasil penelitian ini juga didukung oleh penelitian yang dilakukan Waneen W. Spirduso and Lesli A. Asplund (1995) ${ }^{14}$, dikatakan terdapat pengaruh aktivitas fisik terhadap fungsi kognitif pada lansia. Pada penelitian ini, aktivitas fisik dinilai dapat memengaruhi fungsi kognitif yaitu seperti olahraga aktif/berenang, jalan kaki, berkebun, atau latihan fisik. Dikatakan aktivitas fisik dapat mempertahankan aliran darah yang optimal dan juga meningkatkan penghantaran nutrisi ke otak, selain itu aktivitas fisik juga memfasilitasi metabolisme neurotransmiter, menghasilkan faktor tropik yang merangsang proses neurogenesis, meningkatkan stimulasi aktivitas molekuler dan selular di otak yang nantinya mendukung dan menjaga plastisitas otak. Proses-proses ini penting untuk menghambat hipertrofi jaringan otak yang dapat menyebabkan degenerasi neuronal yang berdampak terhadap kognitif. ${ }^{15}$

Penelitian yang dilakukan Budi Riyanto Wreksoatmodjo (2015) ${ }^{16}$, dikatakan aktivitas kognitif yang buruk pada lansia akan memperbesar risiko fungsi kognitif yang buruk pula. Para lanjut usia yang tidak pernah masak sendiri dua kali lebih berisiko, mereka yang tidak pernah menonton acara berita di televisi dua kali lebih berisiko, mereka yang tidak mempunyai hobi hampir dua kali lebih berisiko, dan mereka yang tidak pernah membaca koran atau buku hampir satu setengah kali lebih berisiko mempunyai fungsi kognitif buruk dibandingkan dengan mereka yang lebih dari sekali seminggu melakukan kegiatan-kegiatan tersebut. Hasil ini berhubungan dengan teori cognitive reserve hypothesis dimana dikatakan orang yang beredukasi memiliki 


\section{Research Article}

lebih banyak sinaps di otak dan mampu mengkompensasi dengan baik terhadap hilangnya suatu kemampuan.

Penelitian yang dilakukan Marlina Dwi Rosita (2012) ${ }^{17}$, menunjukkan terdapatnya hubungan yang signifikan antara fungsi kognitif dengan kemampuan interaksi sosial pada lansia di Kelurahan Mandan wilayah kerja Puskesmas Sukoharjo. Hasil penelitian menunjukkan bahwa fungsi kognitif sebagian besar lansia adalah baik yaitu sejumlah 43 responden $(53,8 \%)$, demikian juga kemampuan interaksi sosial sebagian besar lansia hasilnya adalah baik yaitu sejumlah 47 responden (58,8\%). Hasil uji Chi Square diperoleh $p=0,009$, maka H0 ditolak. Dimana H0-nya adalah tidak ada hubungan antara fungsi kognitif dengan kemampuan interaksi sosial pada lansia di Kelurahan Mandan wilayah kerja Puskesmas Sukoharjo. Menurut beberapa penelitian, semakin banyak hubungan dan aktivitas sosial diasosiasikan dengan semakin lambatnya penurunan kognitif dan mereka yang menerima dukungan emosional mempunyai fungsi kognitif lebih baik. Sebaliknya, seseorang yang tidak mau berinteraksi sosial dengan baik dan tidak mampu beradaptasi dengan perubahan sosial akan menimbulkan reaksi stres dimulai dengan meningkatnya produksi glukocorticoid dan ini berpengaruh terhadap hipotalamus selanjutnya secara perlahan akan memengaruhi fungsi kognitifnya. ${ }^{17}$

\section{Simpulan}

Terdapat hubungan antara umur, tingkat pendidikan, aktivitas fisik, aktivitas kognitif, dan interaksi sosial dengan fungsi kognitif pada populasi lansia. Tidak terdapat hubungan antara jenis kelamin dengan fungsi kognitif pada populasi lansia.

Sebagai saran, perlu dilakukan penelitian lanjutan yang lebih luas mengenai faktorfaktor lain seperti riwayat penyakit yang mungkin berhubungan dengan fungsi kognitif pada lansia, dilakukan pada jumlah subjek penelitian yang lebih besar dan luas jangkauannya, dilakukan tindakan untuk meningkatkan dan memperbaiki fungsi kognitif pada lansia dengan cara edukasi, konseling, dan tindakan - tindakan promotif lainnya, serta dilakukan tindakan untuk mencegah penurunan fungsi kognitif sejak dini terhadap masyarakat pada umumnya.

\section{Daftar Pustaka}

1. Nugroho W. Keperawatan gerontik dan geriatrik 3rd ed. Jakarta: Penerbit Buku Kedokteran EGC; 2008.

2. Martono H. Gerakan nasional pemberdayaan lanjut usia. Jakarta: Gemari; 2008.

3. Badan Pusat Statistik. Statistik penduduk lanjut usia 2013. Jakarta: Badan Pusat Statistik; 2014.

4. Soejono C. Pengkajian paripurna dalam pasien geriatri. Jakarta: Pusat Penerbitan Ilmu Penyakit Dalam Fakultas Kedokteran Universitas Indonesia; 2006.

5. Nadesul H. Menyayangi otak. Jakarta: Penerbit Buku Kompas; 2011.

6. Davey P. Medicine at a glance. John Wiley \& Sons; 2010.

7. Chertkow H. Alzheimer's \& Dementia: The journal of the alzheimer's association. Alzheimers Dement. 2007;3(4):152. 


\section{Research Article}

8. Rachmawati SD, Puspitosani WA. Pengaruh jenis kelamin, pendidikan dan status perkawinan terhadap terjadinya demensia pada lansia. Fakultas Kedokteran Universitas Muhammadiyah Yogyakarta; 2008.

9. Carlo A, Baldereschi M, Amaducci L, Maggi S, Grigoletto F, Scarlato G, Inzitari D. Cognitive impairment without dementia in older people: prevalence, vascular risk factors, impact on disability. The Italian Longitudinal Study on Aging. J American Geriatrics Soc. 2000;48(7):775-82.

10. Scanlan JM, Binkin N, Michieletto F, Lessig M, Zuhr E, Borson S. Cognitive impairment, chronic disease burden, and functional disability: a population study of older Italians. American J Geriatric Psychiatry. 2007;15(8):716-24.

11. Rait G, Fletcher A, Smeeth L, Brayne C, Stirling S, Nunes M, Breeze E, Ng ES, Bulpitt CJ, Jones D, Tulloch AJ. Prevalence of cognitive impairment: results from the MRC trial of assessment and management of older people in the community. Age and ageing. 2005;34(3):242-8.

12. Sjahrir H, Ritarwan K, Tarigan S, Rambe A, Darfika I, Lubis BI. The mini mental state examination in healthy individuals in Medan, Indonesia by age and education level. Neural J Southeast Asia. 2001;6:19-22.

13. Caamaño-Isorna F, Corral M, Montes-Martínez A, Takkouche B. Education and dementia: a meta-analytic study. Neuroepidemiology. 2006;26(4):226-32

14. Spirduso WW, Asplund LA. Physical activity and cognitive function in the elderly. Quest. 1995;47(3):395-410.

15. Muzamil MS, Martini RD. Hubungan antara tingkat aktivitas fisik dengan fungsi kognitif pada usila di Kelurahan Jati Kecamatan Padang Timur. Jurnal Kesehatan Andalas. 2014;3(2).

16. Wreksoatmodjo BR. Aktivitas kognitif mempengaruhi fungsi kognitif lanjut usia di Jakarta; 2015.

17. Dwi Rosita M. Hubungan antara fungsi kognitif dengan kemampuan interaksi sosial pada lansia di Kelurahan Mandan Wilayah Kerja Puskesmas Sukoharjo (Doctoral dissertation, Universitas Muhammadiyah Surakarta); 2012. 